\title{
Serving Generation 1.5: Academic Library Use and Students from Non- English-Speaking Households
}

\author{
Curt Asher, Emerson Case, and Ying Zhong
}

This study examined ways in which the library is utilized by students of Generation 1.5. Generation 1.5 refers to those students who appear fully conversant in English but are in reality still learning the language. The study is based on a survey of 1,396 students at California State University, Bakersfield. Patterns of library use between Generation 1.5 students and their non-Generation 1.5 counterparts were found to differ. The results indicated that, to Generation 1.5 students, the library is a particularly important provider of a physical space, unstructured social learning, and technology.

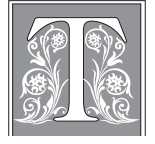

his study examined the ways in which academic library resources are utilized by students who have come to be termed "Generation 1.5." Generation 1.5 students are those who appear fully conversant in American English and culture but are still in the process of learning English when they enter college. ${ }^{1}$ These students live in non-English-speaking households but attended high school in English in the United States. Often, these students exhibit library research difficulties.

Figures from the latest U.S. Census show that there are nearly 10 million children between the ages of 5 and 17 who live in households where English is not the primary language. This number continues to grow, representing 18.4 percent of this age group, compared with only
13.9 percent in 1990 . The number is still greater in California, where 42.6 percent of school-aged children are members of non-English-speaking households. ${ }^{2}$ This situation is even more acute in California's San Joaquin Valley, where this study took place.

This article is based on data extracted from 1,396 responses to a 2006 survey on university library use conducted by the authors at California State University, Bakersfield (CSUB). The findings of this study have implications for how academic librarians can develop programs to assist Generation 1.5 students.

\section{Definition of Generation 1.5}

Writing in "Generation 1.5 Students and College Writing," Harklau points out that, "An increasing number of U.S. high school graduates enter college while still in the

Curt Asher is Associate Librarian in the Walter W. Stiern Library, California State University, Bakersfield; e-mail: casher@csub.edu. Emerson Case is Associate Professor in the Department of English, California State University, Bakersfield; e-mail: ecase@csub.edu. Ying Zhong is Senior Assistant Librarian in the Walter W. Stiern Library, California State University, Bakersfield; e-mail: yzhong@csub.edu. 
process of learning English." ${ }^{3}$ Over the past decade, the term "Generation 1.5," which has its origin in an article by Rumbaut and Ima, has come to designate this emerging population. ${ }^{4}$ An understanding of this group is extremely important, given the rise in the number of students whose first language is not English.

Traditionally, however, the field of second-language acquisition has focused on the more familiar group, traditional international or foreign students. As Reid points out, "Many ESL teachers and most textbooks focus on international students, their language problems and language needs. ${ }^{5}$ Most of these students are highly literate and fluent in their native languages, come from relatively privileged and well-educated backgrounds, and have studied English extensively in a classroom setting. These students, which Reid designates as "eye" learners, "have learned English principally through their eyes, studying vocabulary, verb forms, and language rules." As such, they are extremely capable readers who "know, understand, and can explain English grammar." On the other hand, because of "lack of experience, nonnative Englishspeaking teachers, and the culture shock that comes from being immersed in a foreign culture," their listening, speaking, and writing skills are much more limited. ${ }^{6}$

In contrast to international students, Generation 1.5 students, according to Harklau, are so called because they exhibit "traits and experiences that lie somewhere in between those associated with the first and second Generation." These students, she notes, have arrived in the United States at varying ages, have for the most part grown up speaking a language other than English in the home, and have gone through the educational system of the United States. ${ }^{7}$ As Reid explains, these students have learned principally through their "ears." "They listen to friends and siblings, television, grocery clerks and practice English through trial and error," she contends. ${ }^{8}$
These "ear" learners, Reid points out, have several language strengths. The fact that they have graduated from high school in the United States, she claims, has "made them familiar with class structure and expectations; they have opinions on current controversies and issues; they recognize cultural references to, for instance, television programs, cartoon humor, and advertising." ${ }^{9}$

Having learned English through their ears and in natural settings, most have highly developed conversational skills and advanced listening abilities. "Typically," Reid explains, "they are orally fluent (if not accurate) with highly developed listening skills, they use phrasal verbs, reduced forms, and complex sentence structures easily, naturally; their vocabulary competence (if not vocabulary performance) and cultural knowledge is broad." 10

On the other hand, Reid points out, "it is probable that many 'ear' learners actually do not learn well by hearing/ listening, and that they struggle intensely to learn English aurally. An ineffective 'ear' learner, for instance, may never hear inflections: the common endings of verb tenses, possessives, plurals, or verb agreement. In oral English, inflections are often reduced (and so not heard, even by native English speakers), so 'ear' learners may, in fact, not notice their existence, in conversation or even in reading. Consequently, the language problems of 'ear' learners differ from those of 'eye' learners, and the solutions to those language problems are therefore different."11

Thonus seconds this opinion, stating that "it is essential to recognize certain key differences between Generation 1.5 and other college-level" students. Generation 1.5 students, she states, "face different socioeconomic and sociocultural realities." Such students, she claims, "are often the first in their families to accomplish at least one of the following: (a) become literate in any language, (b) complete high school, (c) attend college." They may also "have experienced marginalization in their elementary and secondary educa- 
tions because of their perceived minority status. They may have been assigned to English language development and remedial classes and relegated to noncollege preparatory coursework. They may even have been steered toward vocational and community college postsecondary options." ${ }^{\prime 2}$

As a result, Harklau explains, while they may have attended schools in the United States, because their experiences have been primarily using another language at home or with their friends, they lack the full range of academic English required in a university setting. ${ }^{13}$

\section{Literature Review}

\section{Academic Literacy Needs}

Much of the literature in the field of second-language acquisition has been influenced by the ideas of Cummins, who posits two different types of language learning: Basic Interpersonal Communication Skills (BICS) and Cognitive Academic Language Proficiency (CALP). The cognitively less-demanding BICS skills are those used to perform basic, daily functions and are used by language learners in such informal settings as the school bus, playground, or lunchroom. The cognitively more-demanding CALP skills, in contrast, are needed for more formal literacy obtainment and are used in the relatively more formal setting of the classroom. While BICS skills can be learned fairly easily and quickly, estimates are that CALP skills may take as long as 5 to 7 years to master. Without CALP skills, however, students will be unable to be academically successful. ${ }^{14}$

Using this distinction as a basis, subsequent research has been carried out to determine what specific academic literacy skills are needed by second-language students to ensure academic success, especially at the college level. Using surveys, for example, Saville-Troike, ${ }^{15}$ Bridgeman and Carlson, ${ }^{16}$ Horowitz, ${ }^{17}$ and Ostler ${ }^{18}$ attempted to assess what types of academic tasks students were asked to perform in their college courses. Christison and
Krahnke $^{19}$ and Leki and Carlson ${ }^{20}$ examined students' needs from the students' own perspectives. Additional studies by Currie $^{21}$ and Shuck ${ }^{22}$ focused on the needs of students in university writing courses.

\section{Studies on Generation 1.5}

Originating in a report by Rumbaut and $\operatorname{Ima}^{23}$ on the adaptation of refugee youth in Southern California, the term " $1.5^{\prime}$ Generation" was originally used in reference to children from Vietnam, Cambodia, Indochina, and Laos. Such students, they claimed, were "neither part of the 'first' Generation of their parents, the responsible adults who were formed in their homeland, who made the fateful decision to leave it and to flee as refugees to an uncertain exile in the United States, and who are thus defined by the consequences of that decision and by the need to justify it; nor are these youths part of the 'second' Generation of children who are born in the U.S., and for whom the 'homeland' mainly exists as a representation consisting of parental memories and memorabilia, even though their ethnicity may remain well defined."

With the 1999 publication of Generation 1.5 meets college composition: Issues in the teaching of writing to U.S.-educated learners of ESL, edited by Harklau, Losey, and Siegal, the term "Generation 1.5" took on a new and expanded role in the study of second-language acquisition. Recognizing that "Long-term U.S. resident English learners pose a significant challenge to the conventional categories and practices governing composition instruction at the postsecondary level," Generation 1.5 uses case studies and interviews to provide detailed profiles of "the backgrounds, attitudes, and college experiences of language minority students" as they come to grips with writing in the American university setting and examines "the high school and college classroom setting in which language minority students learn to write," all from the perspective of the students themselves. By examining both the strengths and weaknesses of the di- 
verse writing programs that educate Generation 1.5 students, the book attempts "to initiate a dialogue on the linguistic, cultural, and ethical issues that attend teaching college writing to U.S. educated linguistically diverse students." ${ }^{24}$

Following in the footsteps of Harklau et al., subsequent studies have attempted to narrow and focus the study of Generation 1.5 students. Several studies, for example, have focused on the various aspects of teaching writing to Generation 1.5 students. Centering on university writing center services and staff, for example, Thonus has examined how the writing center can assist Generation 1.5 students in achieving academic success by developing the necessary writing skills. Thonus first looks at the assumptions that writing center leaders and staff hold regarding Generation 1.5 students, then provides specific strategies for working effectively with such students. ${ }^{25} \mathrm{~A}$ further study by Holten describes a special hybrid composition course for Generation 1.5 students that blends together components from both an ESL program and a mainstream composition course..$^{26}$ Additional reports by Schwartz ${ }^{27}$ and Singhal ${ }^{28}$ describe efforts to more effectively mainstream Generation 1.5 students into traditional university courses.

Subsequent studies have focused on attempts to provide more comprehensive approaches to dealing with Generation 1.5 students. Forrest, for example, details suggestions for developing an effective literacy program for Generation 1.5 students at the high school level, providing recommendations on how curriculum development can meet the needs of learners and how educators can influence the process. ${ }^{29}$ Goldschmidt and Ziemba ${ }^{30}$ describe a university program in which Generation 1.5 students are asked to take a comprehensive American Studies Course Cluster, including a first-year seminar course, an American Studies course, an English grammar course, a developmental composition course, and a college reading and study skills course.
Peterman, ${ }^{31}$ Blumenthal, ${ }^{32}$ and Miele ${ }^{33}$ report on research that examines the experiences of Generation 1.5 students in community colleges.

\section{Generation 1.5 and the Academic Library}

Unfortunately, none of the studies referenced above include components examining the role of the academic library in the success of Generation 1.5 students, and there has been little else written on the learning relationship between Generation 1.5 students and the academic library. It is an area that demands more research, given the dramatic rise within the U.S. population of students whose first language is not English.

Despite the general lack of Generation 1.5 resources, there have been numerous studies examining the relationship between the U.S. academic library and learners of English as a second language, particularly learners who are international students. One of the key differences between international students and Generation 1.5 students is that international students who attend an American university have taken part in an educational process in their own language in their home country and often simply need to transfer the knowledge that they have acquired from their native language to English. Generation 1.5 students, on the other hand, are still in the midst of an educational process and are trying to learn that educational process for the first time, all in a language they may still be in the process of acquiring.

Despite the differences, ESL students in information competency instruction programs face language obstacles that have parallels in the Generation $1.5 \mathrm{com}$ munity. For example, in 1988 Koehler and Swanson wrote that ESL students generally do not understand the bibliographic search process. In a passing reference to Generation 1.5 students, they wrote: "It is indeed rare for ESL students-even those with diplomas from American high schools - to have a sound working familiarity with bibliographic material. Most 
students have, at best, a foggy notion of how to walk into the library with a topic and walk out with source material." ${ }^{\prime 34}$ Other parallels Koehler and Swanson mention are cultural mores that may inhibit students from seeking assistance and an English vocabulary so limited that searching is difficult. ${ }^{35}$

In a study conducted at San Jose State University, Jackson found that international students are often very familiar with library technology when they arrive at the university. ${ }^{36}$ Jiao and Onwuegbuzie, on the other hand, noted that "mechanical barriers" are often the greatest sources of library anxiety among international students. ${ }^{37}$ By comparison, earlier research by two of the present authors found that Generation 1.5 students tend to be more capable of book-based information retrieval than their non-Generation 1.5 counterparts but tend to lack their counterparts' technological savvy. ${ }^{38}$ Additionally, many Generation 1.5 students from disadvantaged backgrounds may see greater academic gains in environments like that of CSUB, where the majority undergraduate population is Hispanic. According to sociologists Portes and Hao, some evidence suggests that such students may feel at less of a disadvantage in the company of coethnic peers. ${ }^{39}$

\section{Methodology}

To examine the attitudes and experiences of Generation 1.5 students in using an academic library at the college level, the authors conducted a campuswide Web survey, funded by a CSUB Research Council Grant in the spring of 2006.

All graduate and undergraduate CSUB students received multiple notices about the survey link via campus e-mail. Students were allowed to complete only one survey. Out of the total 1,363 surveys taken, roughly 95 percent of the respondents $(1,295)$ provided complete data.

The survey included four parts:

1. demographics information (21 questions)

2. library use behavior (14 questions)
3. students' self-evaluation of their information literacy skills (9 questions)

4. satisfaction with and the impact of library services and programs in helping students accomplish their academic work more efficiently and successfully (66 questions)

The focus of this paper is on the data gathered from the first three parts of the survey.

\section{Results}

This study examined Generation 1.5 students' use of, and attitude toward, the academic library versus the uses and attitudes of non-Generation 1.5 students. Two questions were posed in the analysis: 1) What are the commonalities and differences between the two groups? 2) Are there statistical differences that distinguish one group's library use from the other?

Among the survey respondents, nearly 70 percent were under 26 and about 30 percent were 27 to 59 . Female students equaled 75 percent of the respondents. Male respondents totaled 25 percent. The ethnic breakdown of respondents included: 47 percent white, nearly 42 percent Mexican-American or other Latino, 6 percent African American, and 5 percent Asian. Undergraduates constituted 84 percent of the total, with lower-division students representing 26 percent of all respondents and upper-division students comprising the largest contingency at 58 percent. Graduate students represented the remaining 16 percent of respondents. First-generation college students represented 61 percent of responses. Overall, the data collected reflect the demographics of CSUB student population. GPAs distributed fairly evenly among respondents, with 22 percent having GPAs of 2.5 or less, 33 percent with GPAs of 2.6 to 3.0, 27 percent with GPAs of 3.1 to 3.5 , and 18 percent with GPAs of 3.5 or greater.

As a Hispanic-Serving Institution, about 41 percent of CSUB students on the main campus are Latino, with 35 percent of those students of Mexican heritage. At CSUB, the vast majority of Generation 


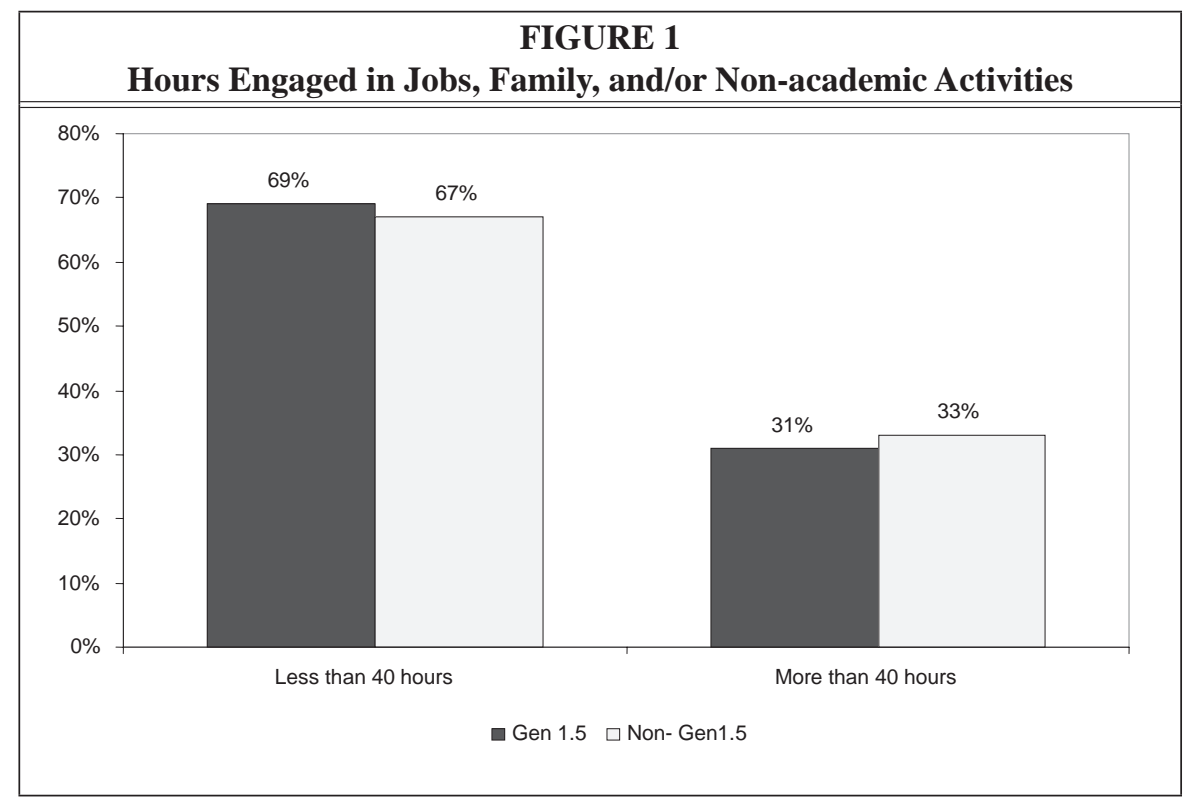

1.5 students are Spanish-speaking children of immigrants who have graduated from American schools. Therefore, to be categorized as Generation 1.5 students, the subjects had to meet two other criteria: 1) they had to indicate their ethnicity as Mexican-American or other Latino, and 2) they had to speak a language other than English at home. Using these criteria, 265 Generation 1.5 students were identified, representing 20 percent of the total group of students surveyed. Survey results closely mirror the makeup of the general population of CSUB.

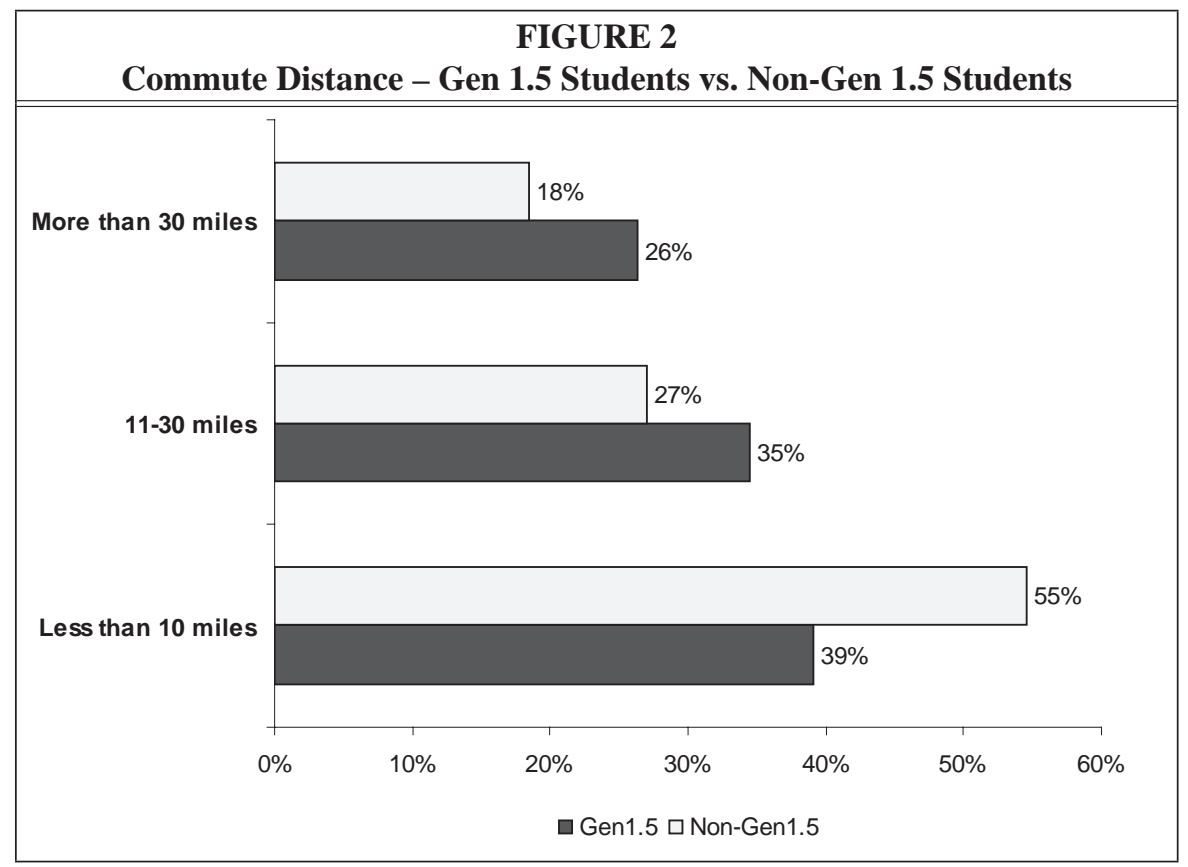




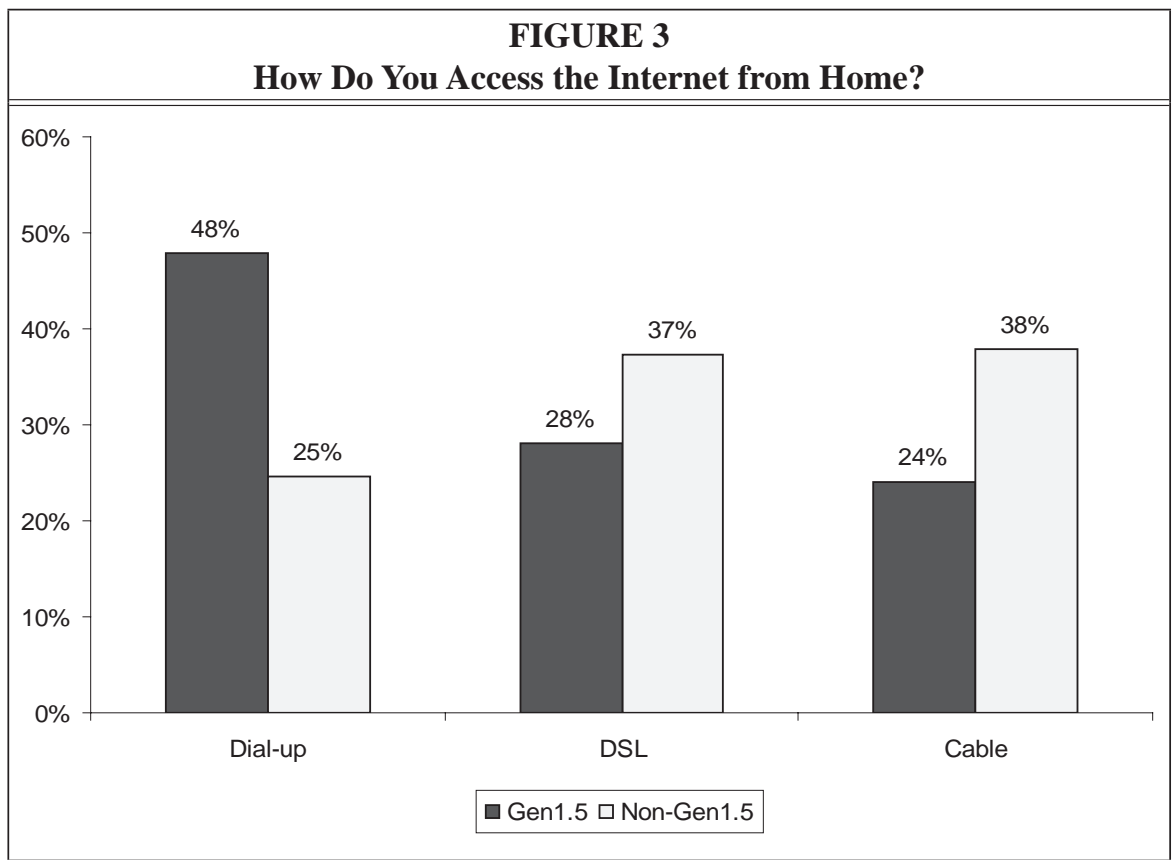

\section{Generation 1.5 Characteristics}

Generation 1.5 students at CSUB were found more often to be recipients of financial aid and are often the first in their families to attend college. They are also more likely to face long commutes to school.

Survey results showed that 74 percent of the Generation 1.5 students were firstgeneration college students, while only 61 percent of the non-Generation 1.5 students were reported to be first-generation college students. Fully 71 percent of the Generation 1.5 students received financial aid, while 59 percent of non-Generation 1.5 students did so.

Figure 1 indicates that Generation 1.5 students spent slightly less time on nonacademic activities and therefore would have more time to spend on their academic work than non-Generation 1.5 students. One explanation could be that most of them had obtained financial aid and therefore didn't have to take offcampus jobs.

In terms of commute distance (figure 2 ), about one quarter of the Generation 1.5 students were living more than 30 miles away from the campus, while only 18 percent of the non-Generation 1.5 students were living that far away. Most non-Generation 1.5 students live close to campus (less than 10 miles), while only 39 percent of the Generation 1.5 students lived within that distance. In the case of CSUB, longer commute distances mean Generation 1.5 students are more likely to be living with their families in small agricultural communities.

\section{Computer and Internet Access}

Although the percentages of students owning computers were similar for Generation 1.5 students and non-Generation 1.5 students, the access rate to the Internet at home for Generation 1.5 students was slightly lower than their non-Generation 1.5 counterparts. Students in the two groups were also found to access the Internet differently (figure 3). Almost half of the Generation 1.5 students were using a dial-up connection, while only 25 percent of the non-Generation 1.5 students were using dial-up. Three-fourths of the non-Generation 1.5 students had high speed Internet access, such as DSL and 


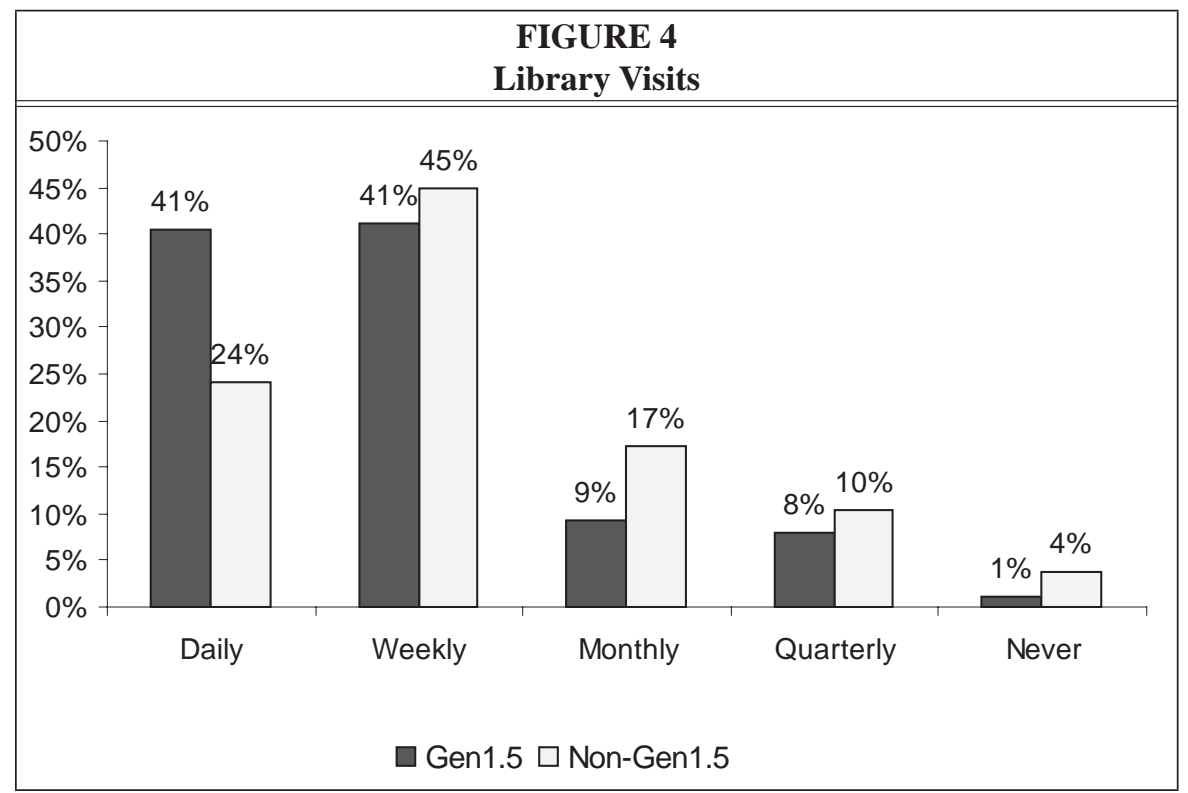

cable, at home, while only 28 percent of the Generation 1.5 students had DSL and only 24 percent had cable.

\section{Library Visits}

Figure 4 indicates that slightly over 40 percent of Generation 1.5 students went to the campus library every day that school was in session, while only 24 percent of the non-Generation 1.5 students were daily visitors to the library. On the other hand, only 9 percent of Generation 1.5 students reported visiting the campus library once a month, while 17 percent

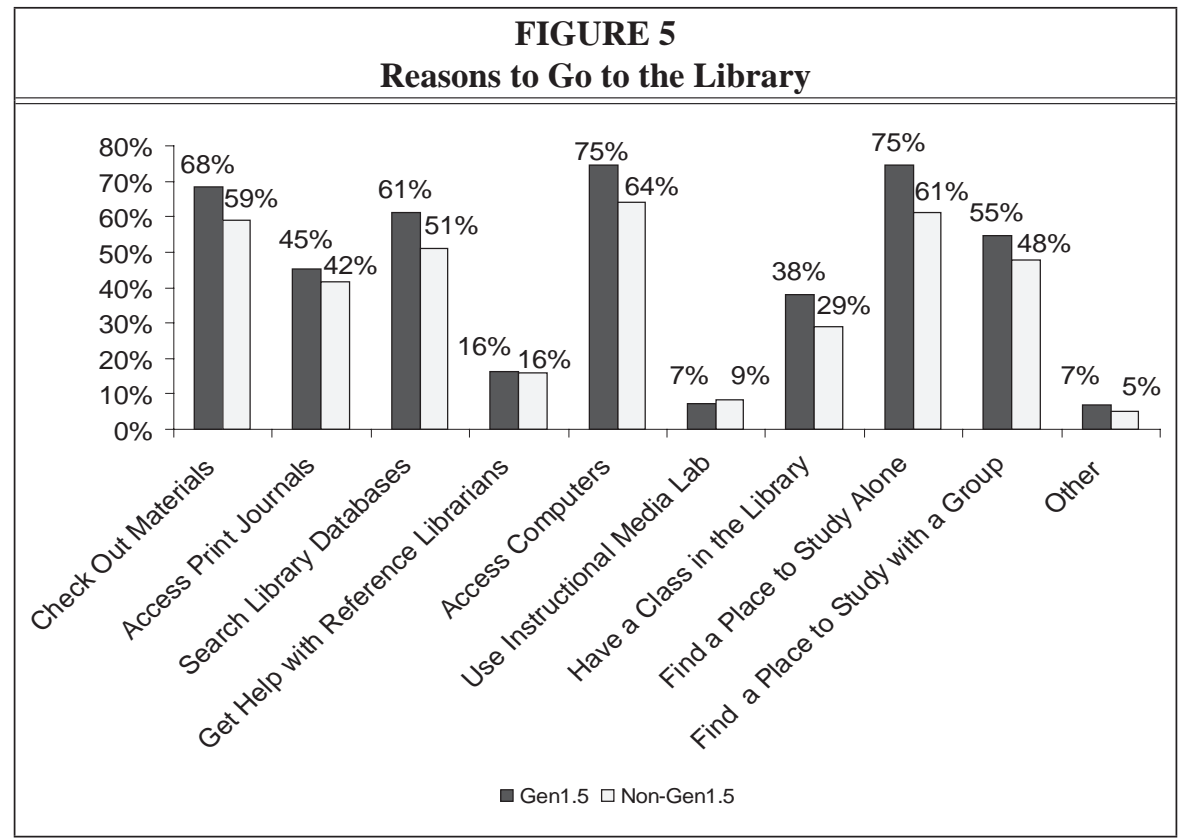




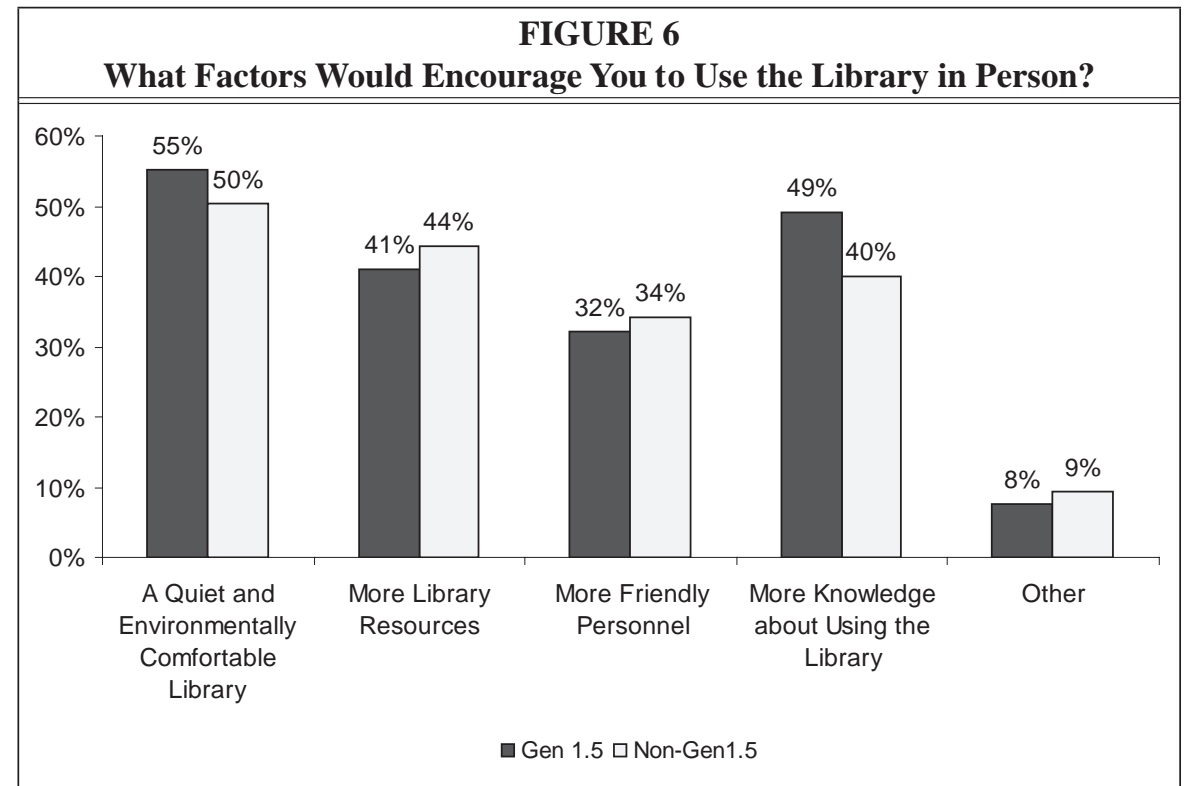

of non-Generation 1.5 students visited monthly. The survey suggests that utilization of the physical library facility is higher for Generation 1.5 students than for other students at CSUB.

Most likely, Generation 1.5 students visited the library to access computers, to find a place to study alone, to check out materials, to search library databases, or to find a place to study with a group. Those were also the top five reasons for nonGeneration 1.5 students to visit the library (figure 5). However, a higher percentage of Generation 1.5 students reported using library facilities and print materials than non-Generation 1.5 students. They also used group study rooms more often than non-Generation 1.5 students.

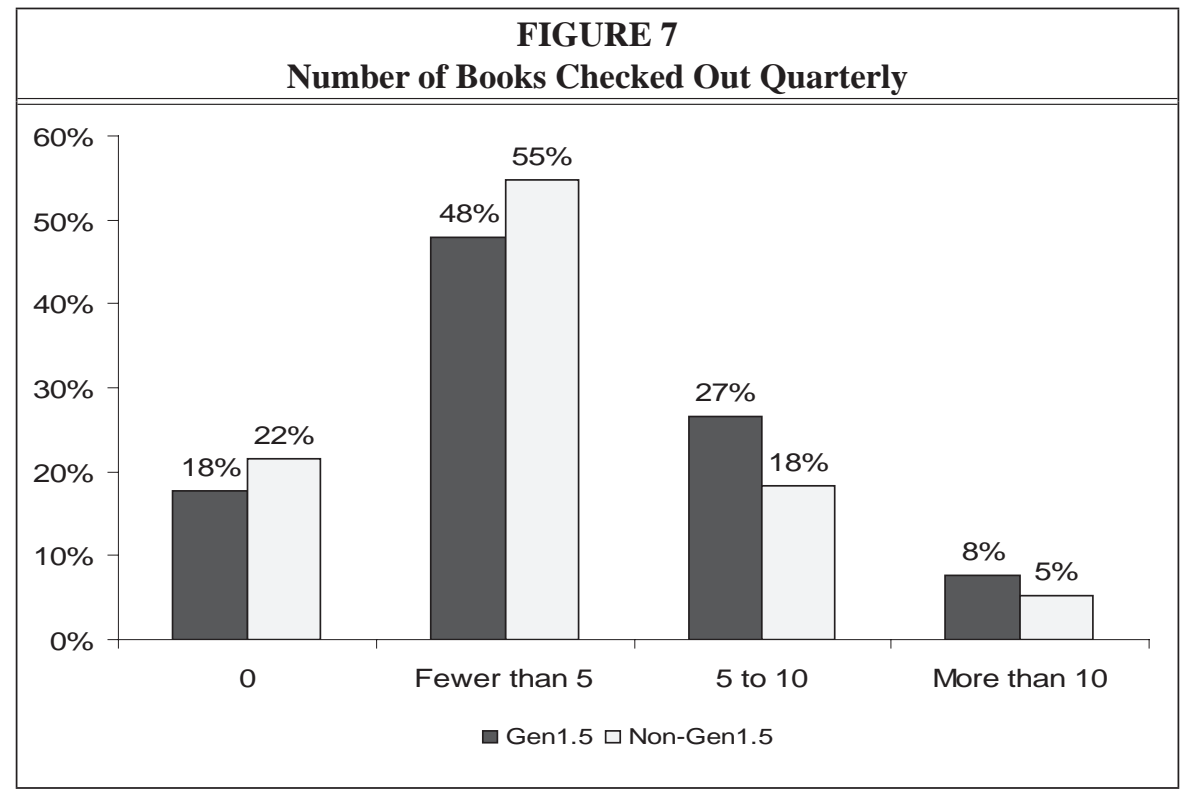




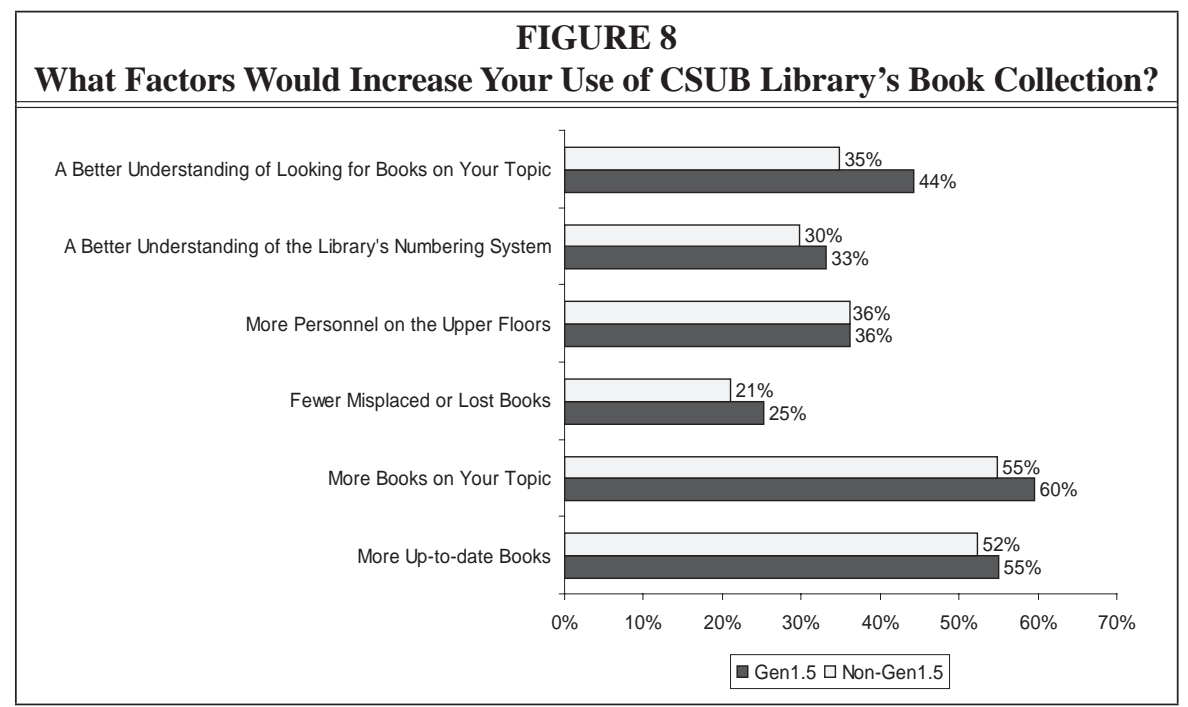

"Library as place" is very important for Generation 1.5 students, as they attached greater value to library facilities than non-Generation 1.5 students (figure 6). Fifty-five percent of the Generation 1.5 students believed that a quiet and comfortable library environment would encourage them to use the library in person. Lack of knowledge was also a hurdle for them. For non-Generation 1.5 students, although library facilities were also the top factor encouraging them to use the library more, a call for more library resources was a more important issue.

\section{Using Books}

The survey suggests that Generation 1.5 students were better users of inprint books and periodicals. Sixty-eight percent of the Generation 1.5 students

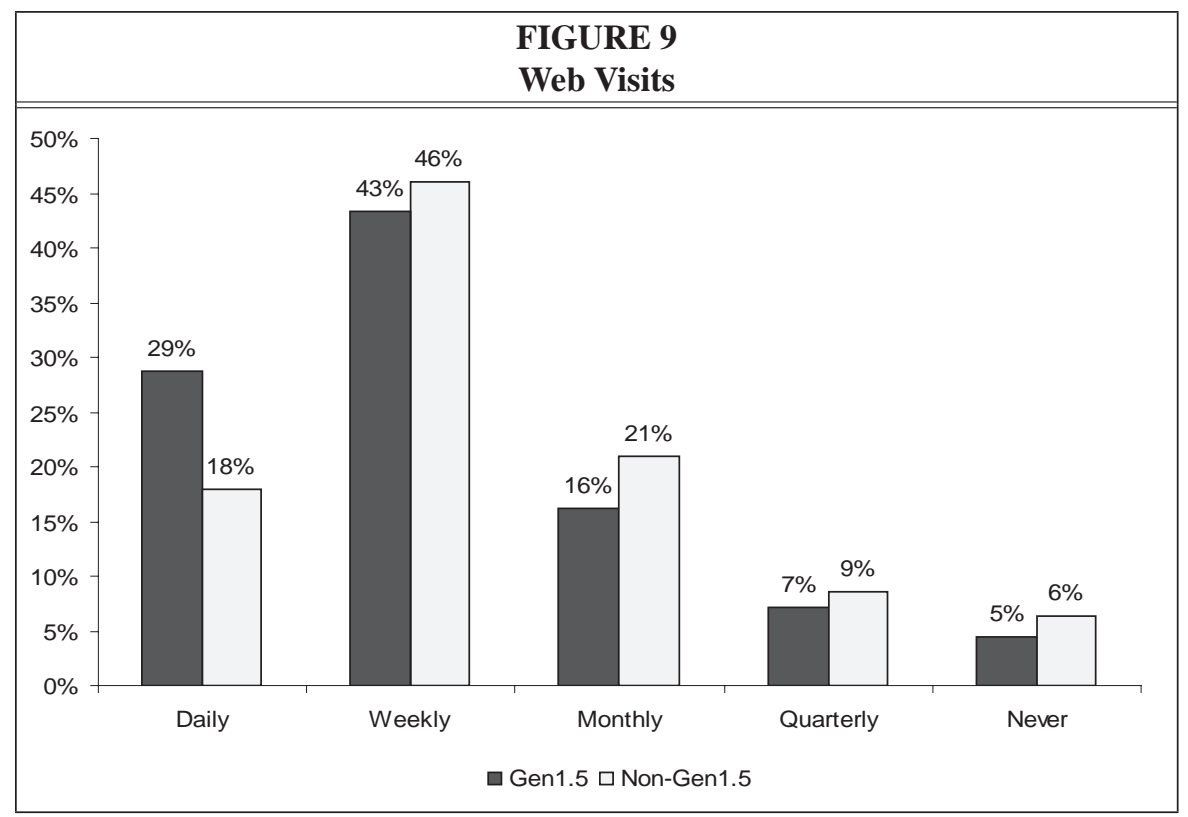




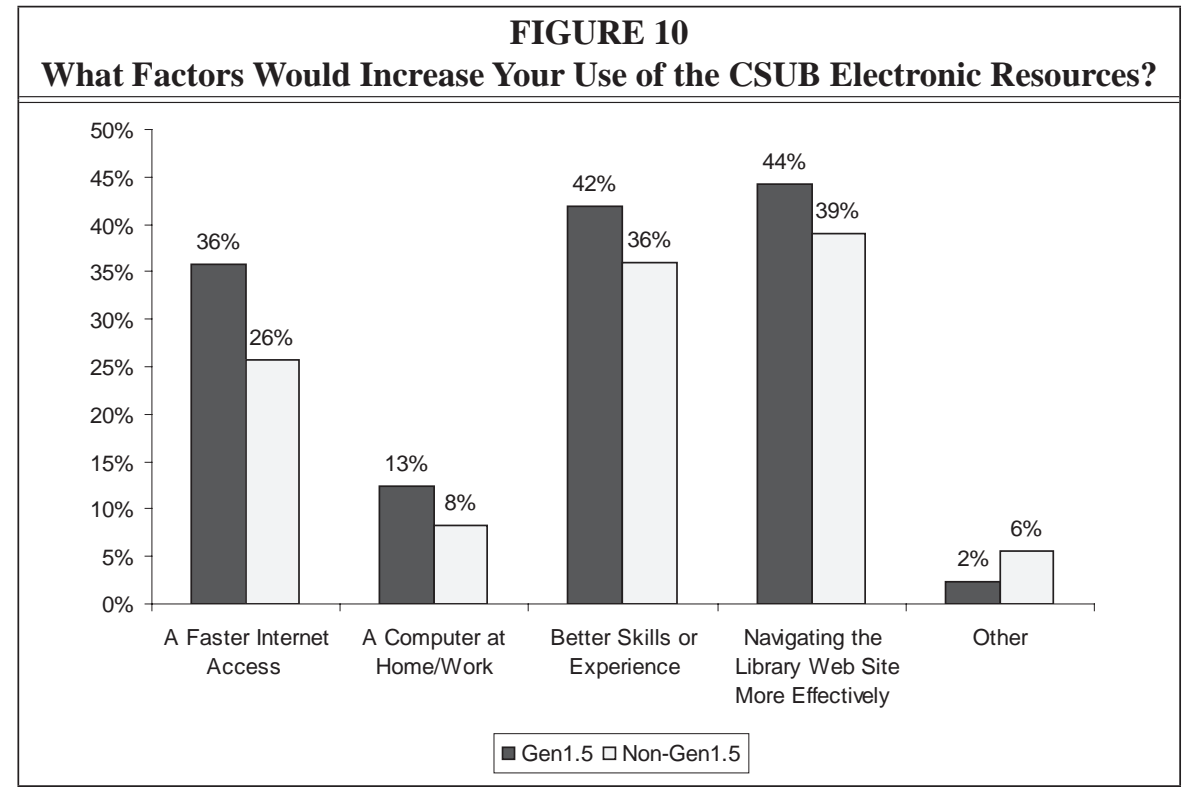

used the library to check out books, compared with 59 percent of the nonGeneration 1.5 students. In terms of using books, figure 7 indicates 27 percent of the Generation 1.5 students checked out 5 to 10 books quarterly, while only 18 percent of the non-Generation 1.5 students did so.
As demonstrated in figure 8, both groups believed that more up-to-date books on their topics of interest would increase their use of the library's book collection. However, 44 percent of the Generation 1.5 students listed having a better understanding of how to search for books on their topic of interest as a

FIGURE 11

You Do Most of Your Research by Using

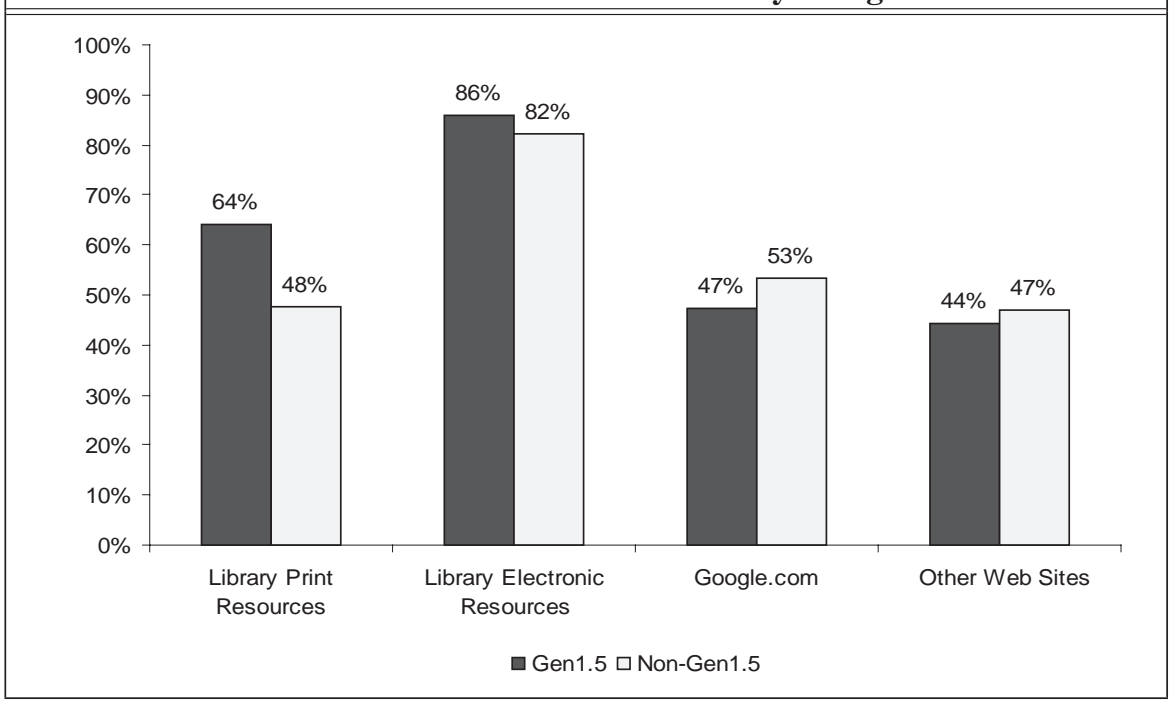




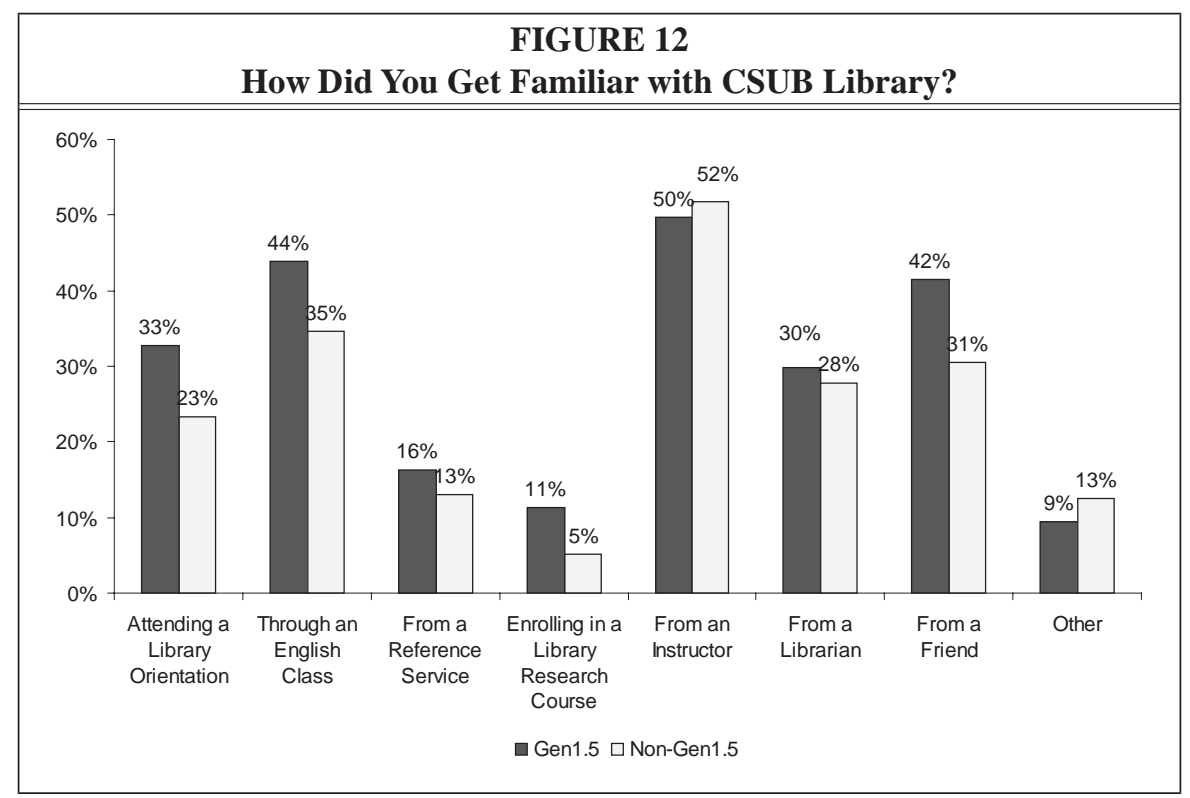

factor for increased library use, compared to only 35 percent of the non-Generation 1.5 students.

\section{Using Electronic Resources}

Generation 1.5 students also accessed the library's Web site more often than nonGeneration 1.5 students (figure 9). About 30 percent of the Generation 1.5 students used the library's Web site on a daily basis compared with only 18 percent of the nonGeneration 1.5 students. The percentages of students who access the library Web site weekly were quite similar for both groups.

Although frequent Web site users, figure 10 indicates Generation 1.5 students were less confident in terms of using CSUB electronic resources. A higher percentage of Generation 1.5 students believed that they would use CSUB electronic resources more if they had better skills/experiences and a more efficient ability to navigate the library Web site. Additionally, limited high-speed Internet access at home also prevented them from using the library's electronic resources.

\section{Research Skills and Library Instruction}

Figure 11 suggests that the two groups do research for their academic work differ- ently. Generation 1.5 students listed library print resources and library electronic resources more often than their counterparts. According to the survey, non-Generation 1.5 students used Google and other Web sites more than Generation 1.5 students.

When asked how he or she got familiar with the CSUB library (figure 12), 50 percent of the Generation 1.5 students and 52 percent of the non-Generation 1.5 students cited their instructors. However, 44 percent of the Generation 1.5 students became familiar with the library via an English class, where a library orientation was integrated, while only 35 percent of the non-Generation 1.5 students became familiar with the library through that course.

Of special note is the fact that 42 percent of the Generation 1.5 students learned about the library from their friends, rather than through more formal means. Peer learning appears to be a particularly important resource, even more important than a librarian or attending a library orientation.

\section{Discussion}

Our results revealed three key differences between the Generation 1.5 and non-Generation 1.5 populations: 1) The library 
is a particularly important provider of a physical space for Generation 1.5 students; 2) The library allows unstructured social learning to take place; and 3) The library is an important provider of technology, even if students have the ability to access technology at home.

These results indicate that Generation 1.5 students value the physical properties of the library building more than their non-Generation 1.5 counterparts. Generation 1.5 students are rushed for time and value the sanctuary of the library as a place to study. Many of the Generation 1.5 students at CSUB commute to campus from small surrounding communities. Many work. Many others live in homes where the environment is not conducive to focused study. As a result, the students tend to make best use of the time and space available while on campus.

The trend in libraries has been a move away from physicality and toward a more diffused, "the library is everywhere" approach. However, quiet rooms where depth of concentration is possible appear to be more important to many of these students than the ability to obtain vast access to an endless sea of research. Obviously, students working at the college level in a language in which they lack fluency require more time to work through their assignments and their research than those students born into the language. In an era of rising expenditures, libraries may need to rethink the precedence of access over space.

Second, many Generation 1.5 students learned how to use the library's resources from friends, but generally they were more likely to use print-based materials. In other words, many of these students gained knowledge, often in a public library environment, of book-based research, probably from friends who passed the knowledge among their social group. Unfortunately, while these students may be gaining research skills in a way that is familiar to them, they are not using the library to its fullest advantage. It is apparent that librarian-led instruction programs and orientations may not be reaching these students to the extent they should. Librarians who teach electronic research skills to Generation 1.5 students may need to follow the teaching model these students have established for themselves: that is to say, classroom settings that provide opportunities for peer-to-peer discussion and social interaction. The present research indicates that such efforts would be particularly advantageous to these students if combined with initial library orientations that offer adequate familiarization with available tools and resources. In addition to instruction, libraries can find other ways to help ensure that there are opportunities for peer-to-peer teaching. Primary among these are providing group study areas where students can share information and knowledge. Further, librarians (and professors collaborating with librarians) working to inculcate information competency in Generation 1.5 students need to develop group learning models that take full advantage of a socially interactive learning style. One effort that may also help is the development of a first-year experience model that introduces library research instruction in practical and socially interactive ways.

Finally, while it is somewhat rare for students to completely lack computer access at home, it is not rare for students, particularly those from poor backgrounds, to have access to older versions of software and slower technology. As a result, many Generation 1.5 students may own a computer and still be completely dependent on the technology that the library provides, which helps to account for their more regular visits to the library and longer use of the facility. Further, although these students do visit library Web sites and use library resources, they feel less confident in their ability to manage technology. One area in which libraries can ease this anxiety is by not only making technology available but ensuring that competent one-on-one assistance in computer technology (as well as information literacy) is provided. 


\section{Conclusion}

Generation 1.5 students tend to graduate from underfunded rural and inner city high school districts where access to electronic research tools may be limited. Underfunded schools tend to seek savings in libraries, where less than adequate funding is available for electronic access to articles, computers, and professional staff.

Three things are obvious: First, students who are most vulnerable are hurt worst by reductions in funding to high school and college libraries. Such cuts are short-sighted at best and, at worst, a sort of institutional discrimination that leaves students from immigrant families unable to compete fairly in college with those who are able to gain experience with electronic materials in other places. Second, reductions in book budgets at the college level further erode the ability of students whose learning has been print-dependent throughout their academic careers. Third, students who come from Generation 1.5 backgrounds could probably benefit most from library-research-skills instruction and training in computer basics because they do not have the experience accessing information electronically that other students may have.

\section{Notes}

1. Linda Harklau, Generation 1.5 Students and College Writing (Washington, D.C.: ERIC Clearinghouse on Languages and Linguistics, 2003), ERIC, ED482491.

2. U.S. Census Bureau, Census 2000. Summary File 3. Table P19 PCT 13 and PCT 14.

3. Linda Harklau, "Generation 1.5 Students and College Writing," Center for Applied Linguistics. Available online at www.cal.org/resources/digest/0305harklau.html. [Accessed 18 June 2006].

4. Rubén G. Rumbaut and Kenji Ima, The Adaptation of Southeast Asian Refugee Youth: A Comparative Study: Final Report to the Office of Resettlement (San Diego, Calif.: San Diego State University, 1988), ERIC, ED 299372 $1-3$.

5. Joy Reid, "Help 'EAR' Learners Avoid Writing Errors," Academic Success Newsletter 3 (2004):

6. Joy Reid, "'Eye' Learners and 'Ear' Learners: Identifying the Language Needs of International Students and U.S. Resident Writers," in Grammar in the Composition Classroom, ed. Joy Reid and Patricia Byrd (New York, N.Y: Heinle \& Heinle Publishers, 1998), 6.

7. Generation 1.5 Meets College Composition: Issues in the Teaching of Writing to U.S.-Educated Learners of ESL, ed. Linda Harklau, Kay M. Losey, and Meryl Siegal (Mahwah, N.J.: Erlbaum, 1999), vii.

8. Reid, "'Eye' Learners and 'Ear' Learners," 4.

9. Reid, "'Eye' Learners and 'Ear' Learners," 4.

10. Reid, "Help 'EAR' Learners Avoid Writing Errors," 1.

11. Reid, "Help 'EAR' Learners Avoid Writing Errors," 1.

12. Terese Thonus, "Serving Generation 1.5 Learners in the University Writing Center," TESOL Journal 12, no. 1 (2003): 18.

13. Harklau, "Generation 1.5 Students and College Writing," 2.

14. Jim Cummins, "Cognitive/Academic Language Proficiency, Linguistic Interdependence, The Optimal Age Question and Some Other Matters," Working Papers on Bilingualism 19 (1979).

15. Muriel Saville-Troike, "What Really Matters in Second Language Learning for Academic Achievement?" TESOL Quarterly 7, no. 4 (1984): 395-405.

16. Brent Bridgeman and Sybil B. Carlson, "Survey of Academic Writing tasks, "Written Communication 1 (1984): 247-80.

17. Daniel M. Horowitz, "What Professors Actually Require: Academic Tasks for the ESL Classroom," TESOL Quarterly 20, no. 3 (1986): 445-62.

18. Shirley Ostler, "A Survey of Academic Needs for Advanced ESL," TESOL Quarterly 14, no. 1 (1980): 489-502.

19. Mary Ann Christison and Karl J. Krahnke, "Student Perceptions of Academic Language Study," TESOL Quarterly 20, no. 1 (1986): 61-81.

20. Ilona Leki and Joan G. Carson, "Students' Perceptions of EAP Writing Instruction and Writing Needs across the Disciplines," TESOL Quarterly 28, no. 1 (1994): 81-101.

21. Pat Currie, "Entering a Disciplinary Community: Conceptual Activities Required to Write for One Introductory University Course," Journal of Second Language Writing 2, no. 2 (1993): 101-17. 
22. Gail Schuck, "Preparing for University Writing Courses: A Survey of Students' Perceptions," Journal of Intensive English Studies 9 (1995): 38-49.

23. Rumbaut and Ima, The Adaptation of Southeast Asian Refugee Youth.

24. Harklau, Losey, and Siegal, vii.

25. Thonus, "Serving Generation 1.5 Learners in the University Writing Center," 17-24.

26. Christina Holten, "Charting New Territory: Creating an International Course for Generation 1.5 Writers," The Catesol Journal 14, no. 1 (2002): 173-89.

27. Gwen Gray Schwartz, "Coming to Terms: Generation 1.5 Students in Mainstream Composition," The Reading Matrix 4, no. 3 (2004): 40-57.

28. Meena Singhal, "Academic Writing and Generation 1.5: Pedagogical Goals and Instructional Issues in the College Composition Classroom," The Reading Matrix 4, no. 3 (2004): 1-48.

29. Scott N. Forrest, "Three Foci of an Effective High School Generation 1.5 Literacy Program," Journal of Adolescent $\mathcal{E}$ Adult Literacy 50, no. 2 (2006): 106-12.

30. Myra Goldschmidt and Christine Ziemba, "Course Clustering: A Comprehensive Program for Generation 1.5," College ESL 10, no. 1-2 (2003): 37-48.

31. Dana S. Peterman, "Generation 1.5 Students in the Community College," Community College Journal of Research and Practice 26 (2002): 683-89.

32. Amy J. Blumenthal, "English as a Second Language at the Community College: An Exploration of Context and Concerns," New Directions for Community Colleges 117 (2002): 45-53.

33. Carol Miele, "Bergen Community College Meets Generation 1.5," Community College Journal of Research and Practice 27 (2003): 603-12.

34. Boyd Koehler and Kathryn Swanson, "ESL Students and Bibliographic Instruction: Learning Yet Another Language," Research Strategies 4 (1988): 148-60.

35. Ibid.

36. Pamela A. Jackson, “Incoming International Students and the Library: A Survey," Reference Services Review 33 (2005): 197-209.

37. Qun G. Jiao and Anthony J. Onwuegbuzie, “Sources of Library Anxiety among International Students," Urban Library Journal 11 (Fall 2001): 16-27.

38. Curt Asher and Emerson Case, "A Generation in Transition: A Study of Usage and Attitudes Toward Public Libraries by Generation 1.5 Students," Reference E Users Services Quarterly 47, no. 3 (2008): 274-79.

39. Alejandro Portes and Lingxin Hao, "The Schooling of Children of Immigrants: Contextual Effects on the Educational Attainment of the Second Generation," Proceedings of the National Academy of Sciences of the United States of America 101 (Aug. 2004): 11920-27. 